\title{
"Ligar gente, lançar sentido: onda branda da guerra" - a propósito da invenção da residência multiprofissional em saúde
}

"To connect people: sweet wave of the war"- about the invention of multiprofessional residence in health

"Unir la gente, lanzar sentido: onda branda de la guerra" - a propósito de la invención de la residencia multiprofesional en salud

Encontro-me, mais uma vez, com o texto de Daniela Dallegrave, acompanhada pela professora Maria Henriqueta Luce Kruse, relativo à invenção da residência multiprofissional em saúde (RMS). Nos encontros anteriores, Daniela formulava um argumento à pesquisa ou interpretava a exploração de campo desse argumento: o que teria motivado as manifestações, provenientes da categoria médica, de vigoroso combate à RMS como modalidade de formação especializada na área? Não era o conjunto do debate sobre a residência (como modalidade de formação especializada e realizada em serviço, mesmo assim historicamente admitida como educação superior pós-graduada) o que se colocava em questão, mas o que teria movido a categoria médica a se manifestar tão veementemente contra a maneira multiprofissional da educação especializada em serviço.

A maneira multiprofissional da educação especializada em serviço é uma das propostas defendidas - no interior das instâncias do Sistema Único de Saúde (SUS) - como resposta à construção da diretriz constitucional do Atendimento Integral na composição de ações e serviços de saúde e sua integração em rede. A defesa da multiprofissionalidade na composição do perfil profissional aparece junto à interdisciplinaridade, nos argumentos do trabalho em equipe, da abordagem biopsicossocial na assistência e à introdução dos conceitos de prevenção, promoção e proteção à saúde, assinalando que esta não é apenas a ausência de doença. Como podia uma prática discursiva de oposição à Integralidade ser enunciada como discursividade pública? O que legitimaria um saber-poder sobre a saúde em desacordo com a integralidade?

Somos apresentados, então, à noção de "invenção cultural", resultante da observação de um abalo ao saber-poder-desejo (cultura) instituído como modelo médico-hegemônico. Abalo provocado pela emergência discursiva da RMS. Não que múltiplas vozes não entoassem esse discurso há muitos anos, mas conservavam-se em uma espécie de marginalidade, clandestinidade, minoridade. Como política ou lei, entretanto, surgia uma nova possibilidade ou potência: tensão ou vetor de divergência ao instituído, oportunidade de território ao instituinte.

A Constituição Federal e a Legislação em Saúde atribuíram ao SUS o papel de ordenador da formação do seu pessoal, estava posto um tensor/vetor em favor dos interesses da sociedade, não os privados ou corporativos de qualquer espécie. As 
Diretrizes Curriculares Nacionais, aprovadas entre 2001 e 2004, afirmaram que a formação básica nas profissões de saúde deveria contemplar - no desenvolvimento das habilidades específicas de cada profissão - a orientação pela integralidade, pelo trabalho em equipe e pela apropriação do SUS, tensor/ vetor de reorientação do ensino de graduação em saúde em favor das necessidades de saúde da população e do sistema público. A RMS punha superior visibilidade a esses objetos (evidência de imagem) e densidade a sua enunciação (evidência de sentido). O que parecia disperso, mostrava-se capaz de "ligar gente, lançar sentido", como compôs Caetano Veloso em A Outra Banda da Terra. Quem sabe, como na música, uma "onda branda da guerra"? Daniela nos mostrou o que pedia visibilidade e qual era a enunciação do polo que "discursava" em favor da RMS: mudança na graduação ("reforma universitária", na linguagem detectada), integralidade, trabalho em equipe, defesa do SUS e reconhecimento das necessidades sociais em saúde. O polo reativo à RMS não precisava inventar um discurso, trabalhava pelo discurso médico-hegemônico, por isso tão facilmente categorizável pela representação corporativa dos médicos.

Atenho-me à delimitação selecionada por Daniela, a disputa entre um regime de verdade instituído (a voz de saber-poder-desejo do modelo médico-hegemônico) e um regime de verdade instituinte (outra voz, a do "Atendimento Integral", presente como diretriz e como princípio do SUS). Daniela localiza, como marcador de tempo e divisor de discursos, o posicionamento do governo federal, no bojo da Política Nacional de Educação na Saúde: Formação Superior e Especializações, período 20032005, que culminou com a criação em lei da Residência em Área Profissional da Saúde (guardando, na medida do possível, correspondência à Residência Médica, de modo que pudessem funcionar como programas integrados). A terminologia da política não era a da Residência Multiprofissional, mas a da oferta de vagas multiprofissionais para o máximo de especialidades, como forma de enfatizar o trabalho em equipe e construir vigorosamente a integralidade. A intenção do governo (e sua linguagem) dava conta de cumprir e fazer cumprir a legislação federal (Art. 30, da Lei 8.080/90, Arts. 39 e 40 da Lei 9.394/96, respeitando a história da precursora residência médica na educação superior).

A reatividade médica, contrária à criação em lei de residências na área da saúde, que não destinadas aos diplomados em medicina, fez emergir a "invenção cultural" da RMS: demandou essa enunciação e gerou essa visibilidade. As entidades médicas, reivindicando a exclusividade da terminologia "residência" à especialização médica, não se mobilizaram para interrogar a criação das Residências em Desenvolvimento de Software, Jurídica, em Agronomia ou a Artística. Foi a acirrada posição das entidades médicas que fez constar, na lei, que a criação da Residência em Área Profissional da Saúde se destinava às profissões da saúde, excetuada a categoria médica (ocorre uma inversão discursiva na linguagem hegemônica: de "médicos e não médicos" para "profissionais de saúde, exceto médicos"). Ao reivindicado prestígio de pertencer a uma instância do Ministério da Educação não correspondia, na gestão da Residência Médica, qualquer correlação com a educação médica de graduação ou com os inúmeros e consolidados programas de residência em outras profissões da área, oferecidos pelas Instituições Federais de Ensino Superior.

No governo, como portador discursivo, Daniela distingue uma bifurcação a partir de julho de 2005: sai da cena da gestão um discurso das residências em área profissional da saúde, em comunicação com o controle social e a participação popular, entra em cena um discurso das residências multiprofissionais role-models. Sai o discurso da singularização (locorregional e por diversificação de cenários), entra o discurso da serialização: programas de formação em massa. Outro portador de discurso foi o segmento dos residentes. Sobre o personagem residente não existir e ter de ser criado, lembro que os residentes existiam, logo, o que se cria é o ator social Movimento de Residentes. Um outro ator, a Associação Nacional dos Médicos Residentes, sucedânea do movimento nacional dos médicos residentes, emergente na história da saúde brasileira como força aliada da reforma sanitária. O antigo ator (movimento de residentes) surpreende o novo ator (movimento emergente de residentes): aquele antigo ator agora distava da luta pelas diretrizes e pelos princípios defendidos como Reforma Sanitária e para incorporação ao SUS! Entre as condições de possibilidade do movimento nacional de residentes em área profissional da saúde está o inusitado desta reação e singularidades históricas, entre elas o estabelecimento da Política Nacional de Educação na Saúde, que se apresentou para o diálogo direto com os estudantes de graduação. Uma multidão de estudantes foi mobilizada no país e teve despertado 
o desejo de se tornar residente do SUS. O Movimento Estudantil foi chamado de maneira especial ao SUS e ao governo federal. Ex-militantes estudantis da área da saúde lideravam a condução política em alguns municípios, abrindo programas de RMS.

Entre outros portadores de discurso, as imagens de revistas e boletins. No relato sobre a capa da revista do Sindicato Médico do Rio Grande do Sul, se imagens valem mais que palavras, o número citado é acachapante relativamente ao tema: uma mão com luva de ferragem empunha um bisturi, sob a frase "Formação multiprofissional da área de saúde: quem ganha com isso?". Legenda, foto e componente central da matéria apontam o risco da inépcia em procedimentos que requerem alta habilidade e põem em risco a vida, mas é exagero especulativo sugerir que a mão tenha apenas 4 dedos. A recíproca do exagero está na anotação de uma entrevista com o então coordenador da Comissão Nacional de Residência Médica, como exemplo de que nem todos os médicos tiveram uma posição contrária à RMS. Em inúmeras manifestações, o mesmo portador discursivo atesta a sua opinião contrária às residências não destinadas a médicos, comemorando seu empenho pessoal para que o Ministério da Saúde não tivesse êxito na atribuição constitucional da ordenação da formação de profissionais e na implementação da obrigação legal de constituir o treinamento especializado em serviço sob supervisão como tarefa intersetorial. A matéria trazia entrevistas com médicos homens que fragilizavam a posição editorial. O ministro que bancou a lei de criação da residência em área profissional da saúde para todas as profissões da área era médico e homem. No polo discursivo do atendimento integral e do trabalho em equipe de saúde, estão inúmeros médicos e homens que fazem intenso uso da palavra escrita e falada a esse favor. Nesse polo também há falas sectárias e outras idealizadas.

Daniela conclui o artigo deixando no ar a necessidade pedagógica da residência como modalidade de formação. Entendo que há, sim, uma necessidade pedagógica da residência para habilitar especialistas. Deveria, então, dialogar amplamente com o controle social e a participação popular, a integralidade, o trabalho em equipe e o desenvolvimento do SUS, portanto, com a multiprofissionalidade. 